\title{
PLANNING THE FLIGHT TRAJECTORY OF A PASSENGER AIRCRAFT WITH REGARDS TO THE ASPECT OF POLLUTANTS EMISSION
}

\author{
Malgorzata Pawlak \\ Gdynia Maritime University, Faculty of Navigation \\ Department of Ship Operation \\ Jana Pawla II Av. 3, 81-345 Gdynia, Poland \\ tel.: +48585586182 \\ e-mail:m.pawlak@wn.umg.edu.pl
}

\begin{abstract}
One of the ways to reduce the adverse impact of aircraft on the environment is through the determination of the trajectory of the flight on a given route that leads to reducing fuel consumption and, consequently, emission of pollutants in jet engines exhausts. Planning a flight in terms of minimizing emissions or fuel consumption is a complex task and difficult to implement due to the conditions in which the aircraft travels, but it is possible though. It is necessary to take into account the limitations resulting from the organization of the airspace and the rules therein, as well as the current weather conditions. The weather is one of the main factors determining the amount of fuel consumed, the time and cost of a particular flight on a given route. In addition to the main parameters, such as pressure and air density, it is extremely important to determine the air temperature, as well as the wind speed and direction. The temperature affects the speed of sound, based on which it is possible to determine the Mach number for a plane flying with a given true air speed (TAS). The speed and direction of wind, on the other hand, affect the speed of the aircraft relative to the ground (velocity over ground, VOG), and thus the duration of its flight. The article describes how the developed model of emission of pollutants in the exhausts of jet bypass engines can be useful for determining the trajectory of an aircraft in its cruise phase due to the criterion of pollutants emissions minimization. An exemplary analysis was carried out for selected aircraft moving along the route adopted for the research. The analysis covered various cruising altitudes and various meteorological conditions (wind speed and direction). The obtained results are illustrated graphically and discussed.
\end{abstract}

Keywords: aircraft, emission, cruise phase, flight trajectory

\section{Introduction}

One of the most important problems inherent in the development of air transport is the deterioration of the air quality, which is caused by the emission of pollutants, which are the products of incomplete combustion of fuel by turbine jet engines, i.e.: nitrogen oxides $\left(\mathrm{NO}_{\mathrm{x}}\right)$, sulphur oxides $\left(\mathrm{SO}_{\mathrm{x}}\right)$, carbon dioxide $\left(\mathrm{CO}_{2}\right)$, carbon monoxide $(\mathrm{CO})$, unburnt hydrocarbons $(\mathrm{HC})$ and particulate matter $(\mathrm{PM})$.

The amount and type of pollutants emitted depends on the type of aircraft, its aerodynamic characteristics, engine type and operating conditions (altitude, flight speed, range of power or thrust), as well as on the type of fuel used. The highest pollution is introduced to the environment by the engines of passenger and transport aircrafts, which are characterized by the highest power and the highest fuel consumption in relation to the generated thrust. During the in-flight, subsonic airplanes, usually operate in the atmosphere, which includes the upper troposphere, tropopause and lower stratosphere.

One of the ways to reduce the adverse impact of aircrafts on the environment is through the determination of the trajectory of the flight on a given route that leads to reducing fuel consumption and, consequently, emission of pollutants in jet engines exhausts. Planning a flight in terms of minimizing emissions or fuel consumption is a complex task and difficult to implement due to the conditions in which the aircraft travels, but it is possible though. It is necessary to take 
into account the limitations resulting from the organization of the airspace and the rules therein, as well as the current weather conditions. The weather is one of the main factors determining the amount of fuel consumed, the time and cost of a particular flight on a given route. In addition to the main parameters, such as pressure and air density, it is extremely important to determine correctly the air temperature, as well as the wind speed and direction. The temperature affects the speed of sound, on the basis of which it is possible to determine the Mach number for a plane flying with a given true air speed (TAS). The speed and direction of wind, on the other hand, affect the speed of the aircraft relative to the ground (velocity over ground, VOG), and thus the duration of its flight $[4,5]$.

\section{The model of pollutants emission in jet engines exhausts}

The research conducted in [6] aimed to develop such a model of emission of pollutants in the exhausts of jet engines of an aircraft that enables the determination of the $\mathrm{CO}, \mathrm{HC}, \mathrm{NO}_{\mathrm{x}}$ and $\mathrm{CO}_{2}$ emissions as well as the fuel consumption in given in-flight conditions. Emphasis was placed on the wide application of the model - for any passenger aircraft equipped with by-pass jet engines, for flights up to a cruising altitude of $11 \mathrm{~km}$ and a flight speed up to $0.85 \mathrm{Ma}$, to be used for flights on different routes (of different lengths), taking into account meteorological conditions (wind direction and speed).

In order to determine the emission of a given pollutant ' $z$ ' in the exhausts of a given aircraft's engines during a cruise phase, the following formula is used:

$$
E_{(z)}=E I_{(z)} \cdot K \cdot S F C \cdot t \cdot l
$$

where:

$E_{(z)}-$ emission of a particular pollutant ' $\mathrm{z}$ ' in the exhausts $[\mathrm{kg}]$;

$E I_{(z)}$ - emission indexes for particular pollutants, depended on the type of engine and the range of its run, indicated at a given cruising altitude $[\mathrm{kg} / \mathrm{kg}$ of fuel $]$;

$K \quad$ - engine thrust [N];

$S F C$ - specific fuel consumption $[\mathrm{kg} /(\mathrm{N} \cdot \mathrm{h})]$;

$t \quad$ - engine run time at a given thrust $[\mathrm{h}]$;

$l \quad-$ number of engines.

Thrust and specific fuel consumption can be derived directly from the engine characteristics. Emission index for $\mathrm{CO}_{2}-E_{\mathrm{CO}_{2}}$ - is proportional to fuel consumption and equals to $3.1555 \mathrm{~kg}$ per $\mathrm{kg}$ of fuel burned by each jet engine. However, emission indexes for other pollutants (HC, $\mathrm{CO}$ and $\mathrm{NO}_{\mathrm{x}}$ ) must be computed. To determine them for a given flight phase, the emission indexes determined for the LTO phase should be reduced to the ambient flight parameters, depending on the flight speed and altitude. These values can be measured during the flight, which is very difficult, or approximated analytically. The speed and altitude characteristics for jet engines can be approximated by means of appropriate transformation of the rotational characteristics of the jet engine.

The dependencies describing changes in ambient pressure and ambient temperature due to changes in altitude and flight speed can be written as follows $[1,8]$ :

$$
\begin{gathered}
T_{c}=T \cdot\left(1+0.2 \cdot \mathrm{Ma}^{2}\right), \\
p_{c}=p \cdot\left(1+0.2 \cdot \mathrm{Ma}^{2}\right)^{3.5},
\end{gathered}
$$

where:

$\mathrm{T}_{\mathrm{c}}, \mathrm{p}_{\mathrm{c}}$ - total temperature $[\mathrm{K}]$ and total pressure $[\mathrm{Pa}]$;

$\mathrm{T}, \mathrm{p}$ - ambient temperature $[\mathrm{K}]$ and ambient pressure $[\mathrm{Pa}]$ at a given flight altitude (according to ISA);

Ma - Mach number. 
On this basis, the formulas for the reduction of emission indexes of particular pollutants can be derived [7]:

$$
\begin{gathered}
E I_{C O}=E I_{\text {COLTO }} \cdot \frac{\theta^{3.3}}{\delta^{1.02}}, \\
E I_{H C}=E I_{H C L T O} \cdot \frac{\theta^{3.3}}{\delta^{1.02}}, \\
E I_{N O X}=E I_{N O X L T O} \cdot \sqrt{\frac{\delta^{1.02}}{\theta^{3.3}}} \cdot e^{h},
\end{gathered}
$$

where:

$E I_{C O} / E I_{N O x} / E I_{H C}-$ emission indexes for particular substances, dependent on the type of engine and the range of its run, determined at a given cruising altitude [ $\mathrm{kg} / \mathrm{kg}$ of fuel],

$\theta$ - temperature change coefficient $[-]$

$$
\theta=\frac{T_{C}}{288.15 K}
$$

$\delta$ - pressure change coefficient $[-]$

$$
\delta=\frac{p_{c}}{101325 P a}
$$

$e-$ Euler number $(e=2.72)$,

$h$ - humidity correction factor, dependent on cruising altitude [-]

$$
h=-19 \cdot(\omega-0.00634) \text {, }
$$

$\omega$ - specific humidity, where $\omega=10^{-3} \cdot e^{-0.0001426 \cdot(H-12900)}$ for ISA, where $\mathrm{H}$ - cruising altitude [feet].

\section{Application of the emission modelin the process of planning the flight trajectory for a passenger aircraft concerning emission}

Application of the developed model of emission of pollutants in the jet engines' exhausts requires using the performance characteristics of the engines used in a given jet aircraft. As already stated, the $\mathrm{CO}_{2}$ emissions can be simply determined - based on the amount of fuel burned during the cruise phase. The emission of other compounds $\left(\mathrm{NO}_{\mathrm{x}}, \mathrm{CO}\right.$ and $\left.\mathrm{HC}\right)$ is, however, strongly dependent on a number of parameters, especially on the type of engine, its power settings, current flight speed, altitude and ambient atmospheric conditions.

The wind speeds and directions have to be taken into account when determining the emission, as they affect the duration of the flight - its shortening in the case of tailwinds and its elongation in the case of headwinds. Duration of the flight in the cruise phase, affects the total emission of harmful compounds in the exhausts. The determination of flight time requires solving the problem of the impact of wind on the speed of the aircraft relative to the ground. The speed of the aircraft is given in relation to the airflow. Taking into account the angle between the direction of the flight and the direction of the wind, there can be determined the speed by which the speed of the aircraft relative to the ground will increase or decrease.

Taking into account the distance covered by the aircraft in a given $i$-segment of the cruise phase, the time of flight in that segment can be determined:

$$
\mathrm{t}_{\mathrm{CRUISE}}=\frac{\mathrm{L}_{\mathrm{CRUISE}}}{\mathrm{v}_{\mathrm{flight}} \mp \mathrm{V}_{\text {wind }} \cdot \cos \alpha_{\text {wind }}},
$$

where:

$t_{\text {CRUISE }}$ - duration of the flight in a given $i$-segment of the cruise phase [h],

$L_{\text {CRUISE }}$ - distance covered by an aircraft in a given $i$-segment of the cruise phase $[\mathrm{km}]$, 
$V_{\text {flight }}$ - airspeed of aircraft $[\mathrm{km} / \mathrm{h}]$,

$V_{\text {wind }}-$ wind speed in a given $i$-segment of the cruise phase $[\mathrm{km} / \mathrm{h}]$,

$\alpha_{\text {wind }}$ - angle between the flight direction and the wind direction in a given $i$-segment of the cruise phase $\left[{ }^{\circ}\right]$.

Total time of the cruise phase, $t$, given in formula (1) constitutes the sum of durations of the flight in all segments of the cruise phase.

The Boeing 737-300 aircraft was selected to conduct the research. It is one of the most popular medium-range passenger aircraft, equipped with bypass jet engines. The aircraft version analysed in the research is equipped with SNECMA CFM-56C engines. The basic technical specifications of the aircraft are given in Tab. 1.

Tab. 1. Basic information and technical data of the Boeing 737-300 aircraft [3]

\begin{tabular}{|c|c|c|c|c|c|c|c|c|}
\hline Model & $\begin{array}{c}\text { Seating } \\
\text { capacity }\end{array}$ & $\begin{array}{c}\text { Length } \\
{[\mathrm{m}]}\end{array}$ & $\begin{array}{c}\text { Wingspan } \\
{[\mathrm{m}]}\end{array}$ & $\begin{array}{c}\text { Engines } \\
\text { type }\end{array}$ & $\begin{array}{c}\text { Thrust } \\
{[\mathrm{kN}]}\end{array}$ & $\begin{array}{c}\text { Maximum take- } \\
\text {-off weight }[\mathrm{kg}]\end{array}$ & $\begin{array}{c}\text { Aircraft } \\
\text { range }[\mathrm{km}]\end{array}$ & $\begin{array}{c}\text { Maximum } \\
\text { speed }[\mathrm{km} / \mathrm{h}]\end{array}$ \\
\hline $\begin{array}{c}\text { Boeing } \\
737-300\end{array}$ & $128-149$ & 33.40 & 28.88 & $\begin{array}{c}\text { 2x Snecma } \\
\text { CFM56-3C }\end{array}$ & $2 \times 140$ & 56742 & 5475 & 912 \\
\hline
\end{tabular}

Figure 1 presents the determined speed and altitude characteristic of the Snecma CFM-56 engine. This characteristic was determined according to the procedure described in [6]. These data will be used to determine the operating parameters and emission corresponding to the parameters of the aircraft flight.

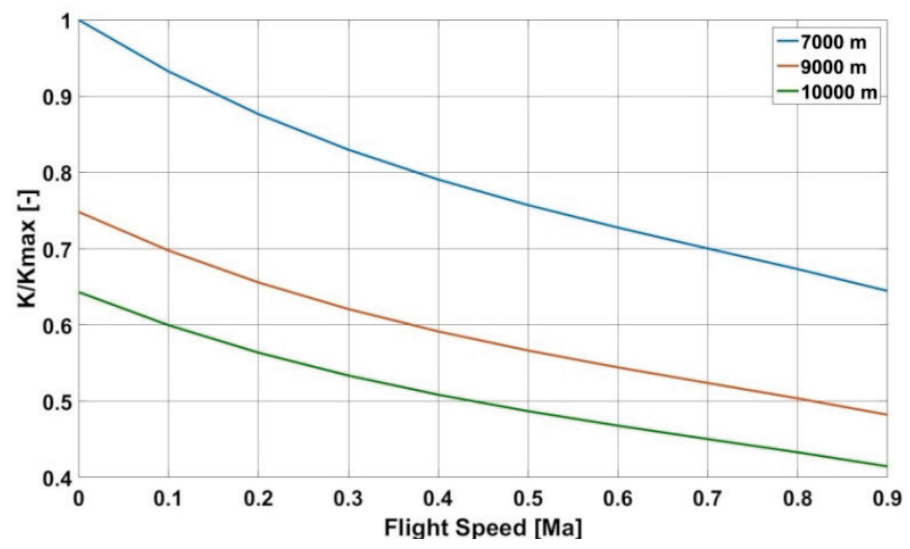

Fig. 1. The speed-altitude characteristics of the Snecma CFM-56 engine

An exemplary route from Copenhagen to Gdansk of the length of $526 \mathrm{~km}$ was taken for the research (Fig. 2).

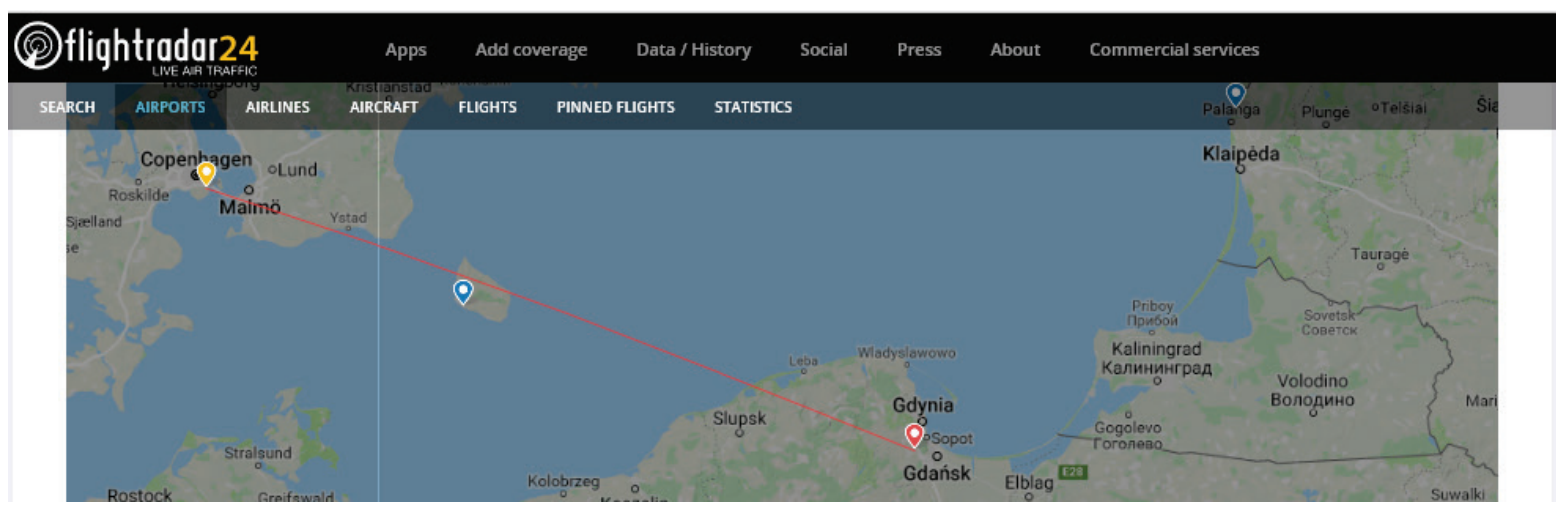

Fig. 2. Visualisation of the flight trajectory between Copenhagen and Gdansk airports (retrieved from [2]) 
The parameters of the exemplary flight carried out on the route taken for the research are shown in Fig. 3.

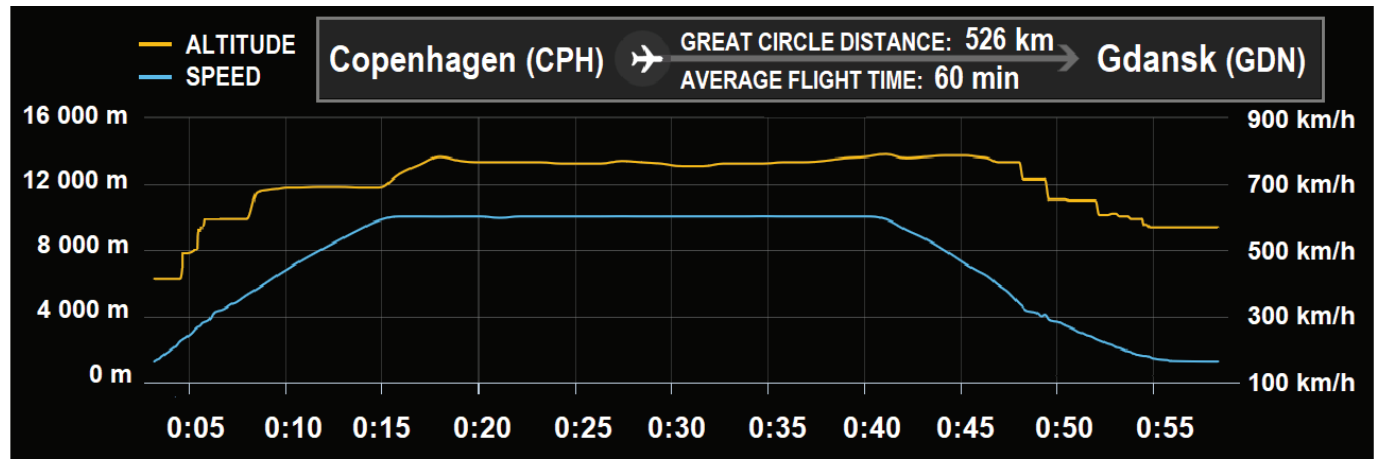

Fig. 3. Adopted trajectory of flight between Copenhagen and Gdansk airports (developed basing on [2])

Three cruising altitudes of 7, 9 and $10 \mathrm{~km}$ were taken for the research. On each of them there was indicated a trajectory, along which the aircraft will travel. A cruise phase of the length of $408 \mathrm{~km}$ was assumed and divided into segments of the length of $24 \mathrm{~km}$. In each of them, the wind direction and speed were determined, based on data retrieved from windy.com [9].

In Fig. 4-6, the red lines indicate the flight trajectories (divided into segments) at the three cruising altitudes, while in Tab. 2-4 the values of wind speed and direction read from the map are presented. The angle between the flight direction and the wind direction $\alpha_{\text {wind }}$ is given in $\left[^{\circ}\right]$.

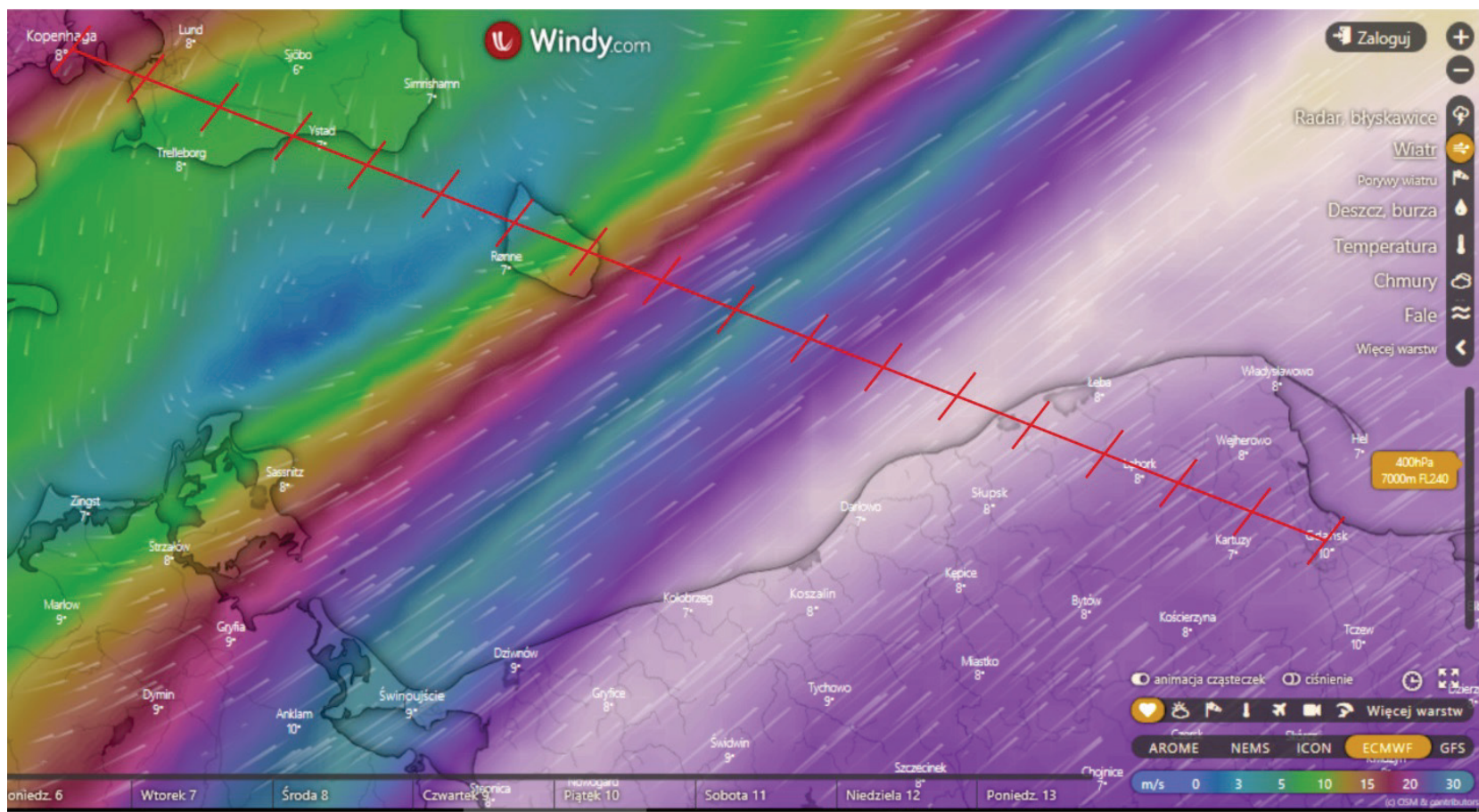

Fig. 4. Flight conditions (wind directions and speeds) on the route of flight carried out at a cruising altitude of $7 \mathrm{~km}$ on 05/05/2019 (the map retrieved from [9])

Tab. 2. Flight conditions (wind directions and speeds) on the route of flight carried out at a cruising altitude of $7 \mathrm{~km}$ on 05/05/2019

\begin{tabular}{|l|c|c|c|c|c|c|c|c|c|c|c|c|c|c|c|c|c|}
\hline Segment No. & I & II & III & IV & V & VI & VII & VIII & IX & X & XI & XII & XIII & XIV & XV & XVI & XVII \\
\hline$V_{\text {wind }}[\mathrm{m} / \mathrm{s}]$ & 18 & 12 & 10 & 10 & 5 & 5 & 10 & 15 & 20 & 20 & 20 & 25 & 25 & 25 & 25 & 25 & 25 \\
\hline$\alpha_{\text {wind }}\left[^{\circ}\right]$ & 91 & 95 & 90 & 75 & 55 & 60 & 70 & 72 & 70 & 73 & 70 & 70 & 70 & 70 & 70 & 70 & 70 \\
\hline
\end{tabular}




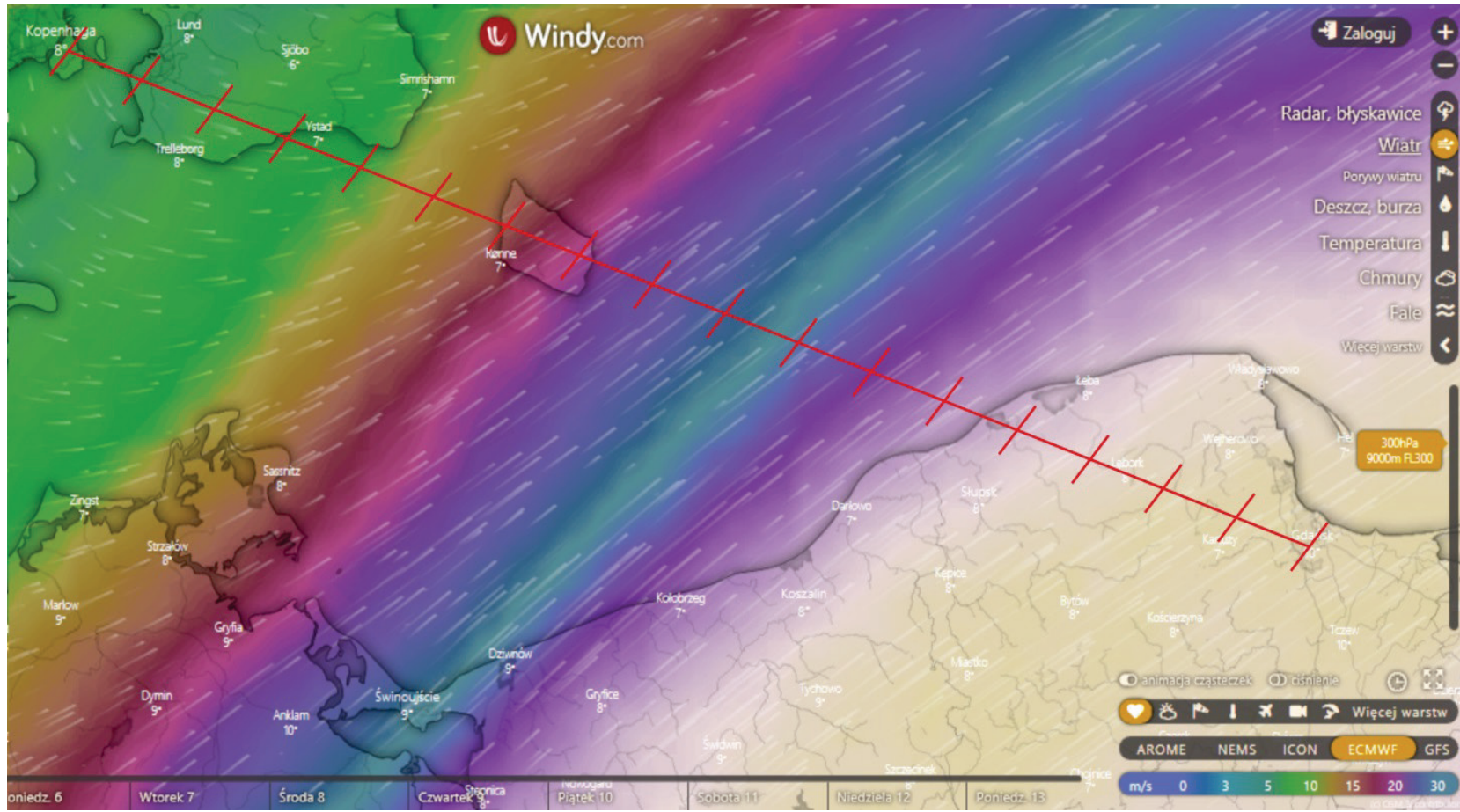

Fig. 5. Flight conditions (wind directions and speeds) on the route of flight carried out at a cruising altitude of $9 \mathrm{~km}$ on 05/05/2019 (the map retrieved from [9])

Tab. 3. Flight conditions (wind directions and speeds) on the route of flight carried out at a cruising altitude of $9 \mathrm{~km}$ on 05/05/2019

\begin{tabular}{|l|c|c|c|c|c|c|c|c|c|c|c|c|c|c|c|c|c|}
\hline Segment No. & I & II & III & IV & V & VI & VII & VIII & IX & X & XI & XII & XIII & XIV & XV & XVI & XVII \\
\hline$V_{\text {wind }}[\mathrm{m} / \mathrm{s}]$ & 10 & 10 & 10 & 10 & 10 & 15 & 15 & 20 & 20 & 22 & 22 & 25 & 25 & 25 & 25 & 25 & 25 \\
\hline$\alpha_{\text {wind }}\left[^{\circ}\right]$ & 30 & 0 & 25 & 25 & 35 & 40 & 53 & 55 & 55 & 56 & 53 & 52 & 53 & 52 & 52 & 52 & 52 \\
\hline
\end{tabular}

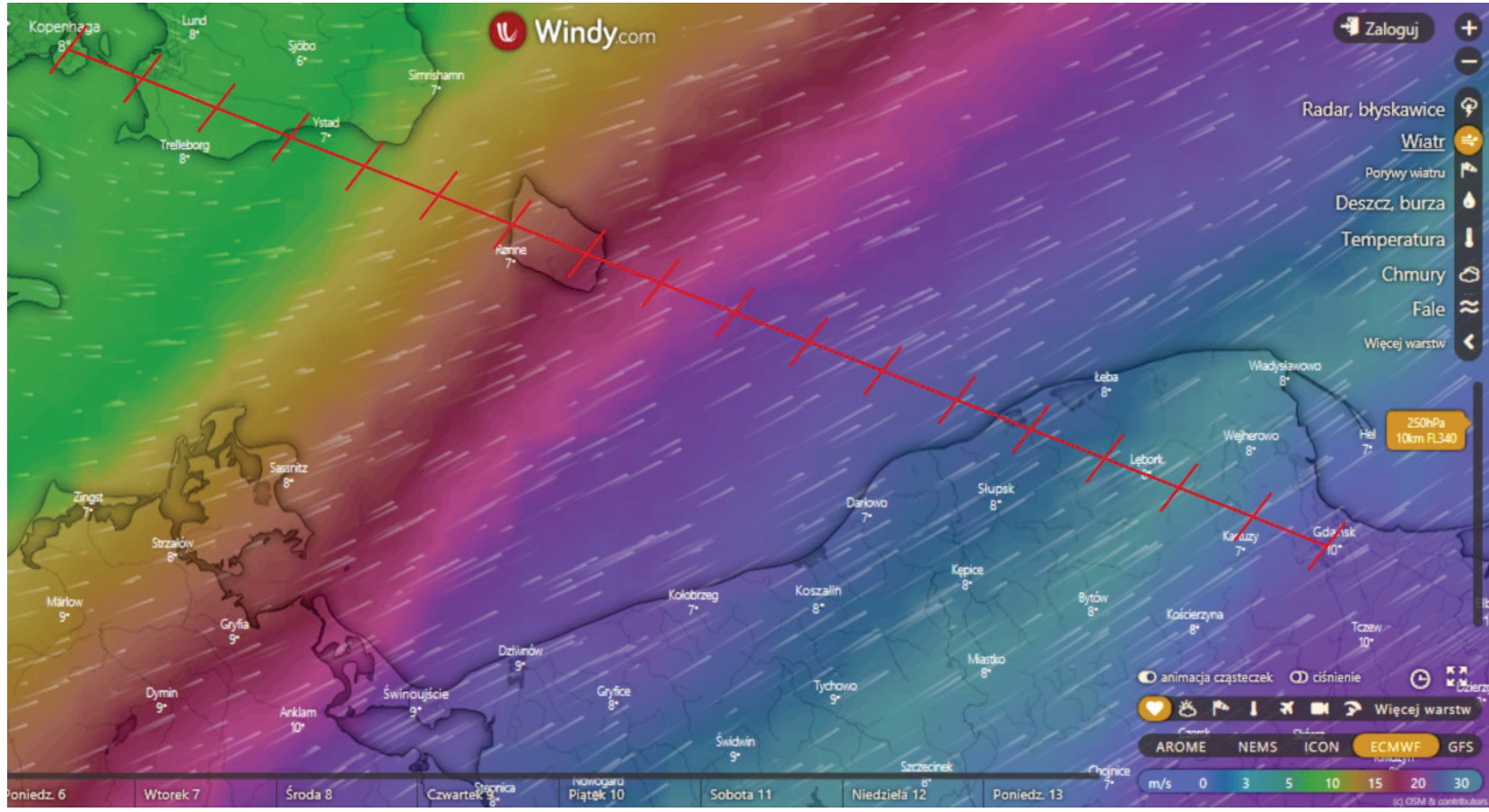

Fig. 6. Flight conditions (wind directions and speeds) on the route of flight carried out at a cruising altitude of $10 \mathrm{~km}$ on 05/05/2019 (the map retrieved from [9]) 
Tab. 4. Flight conditions (wind directions and speeds) on the route of flight carried out at a cruising altitude of $10 \mathrm{~km}$ on 05/05/2019

\begin{tabular}{|l|c|c|c|c|c|c|c|c|c|c|c|c|c|c|c|c|c|}
\hline Segment No. & I & II & III & IV & V & VI & VII & VIII & IX & X & XI & XII & XIII & XIV & XV & XVI & XVII \\
\hline$V_{\text {wind }}[\mathrm{m} / \mathrm{s}]$ & 10 & 10 & 10 & 10 & 10 & 15 & 20 & 20 & 22 & 25 & 25 & 25 & 30 & 30 & 30 & 30 & 30 \\
\hline$\alpha_{\text {wind }}\left[^{\circ}\right]$ & 3 & 20 & 20 & 43 & 42 & 40 & 42 & 43 & 44 & 45 & 45 & 45 & 45 & 45 & 45 & 45 & 45 \\
\hline
\end{tabular}

On the basis of the wind distribution at each cruising altitude and the formula (10), the time of flight in each segment (of $34 \mathrm{~km}$ in length) of cruise phase was determined. Next, the total time of flight in cruising conditions on the route from Copenhagen to Gdansk was computed. The results obtained are presented in Tab. 5-7.

Tab. 5. The time of flight in the cruise phase, taking into account the different flight speeds as well as the direction and speed of wind at cruising altitude of $7 \mathrm{~km}$

\begin{tabular}{|c|c|c|c|c|c|c|c|c|c|c|c|c|c|c|c|c|c|c|}
\hline \multirow{2}{*}{$\begin{array}{c}\text { Flight } \\
\begin{array}{c}\text { speed } \\
{[\mathrm{Ma}]}\end{array}\end{array}$} & I & II & III & IV & V & VI & VII & VIII & IX & X & XI & XII & XIII & XIV & XV & XVI & XVII & $\begin{array}{c}\text { Total } \\
\text { time of } \\
\text { flight } \\
{[\mathrm{min}]}\end{array}$ \\
\hline 0.7 & 110 & 110 & 110 & 109 & 108 & 109 & 108 & 108 & 106 & 107 & 106 & 106 & 106 & 106 & 106 & 106 & 106 & 30.42 \\
\hline 0.8 & 96 & 96 & 96 & 95 & 95 & 95 & 95 & 93 & 94 & 94 & 94 & 93 & 93 & 93 & 93 & 93 & 93 & 26.69 \\
\hline 0.85 & 91 & 91 & 90 & 90 & 89 & 90 & 90 & 89 & 88 & 89 & 88 & 88 & 88 & 88 & 88 & 88 & 88 & 25.15 \\
\hline
\end{tabular}

Tab. 6. The time of flight in the cruise phase, taking into account the different flight speeds as well as the direction and speed of wind at cruising altitude of $9 \mathrm{~km}$

\begin{tabular}{|c|c|c|c|c|c|c|c|c|c|c|c|c|c|c|c|c|c|c|}
\hline \multirow{2}{*}{$\begin{array}{c}\text { Flight } \\
\text { speed } \\
{[\mathrm{Ma}]}\end{array}$} & I & II & III & IV & V & VI & VII & VIII & IX & X & XI & XII & XIII & XIV & XV & XVI & XVII & $\begin{array}{c}\text { Total } \\
\text { time of } \\
\text { flight } \\
{\left[\begin{array}{c}\text { fin }] \\
{[}\end{array}\right.}\end{array}$ \\
\hline 0.7 & 108 & 108 & 108 & 108 & 109 & 107 & 108 & 107 & 107 & 107 & 106 & 105 & 105 & 105 & 105 & 105 & 105 & 30.26 \\
\hline 0.8 & 95 & 95 & 95 & 95 & 96 & 94 & 95 & 94 & 94 & 94 & 94 & 93 & 93 & 93 & 93 & 93 & 93 & 26.66 \\
\hline 0.85 & 90 & 90 & 90 & 90 & 90 & 89 & 90 & 89 & 89 & 89 & 88 & 88 & 88 & 88 & 88 & 88 & 88 & 25.16 \\
\hline
\end{tabular}

Tab. 7. The time of flight in the cruise phase, taking into account the different flight speeds as well as the direction and speed of wind at cruising altitude of $10 \mathrm{~km}$

\begin{tabular}{|c|c|c|c|c|c|c|c|c|c|c|c|c|c|c|c|c|c|c|}
\hline \multirow{2}{*}{$\begin{array}{c}\text { Flight } \\
\begin{array}{c}\text { speed } \\
{[\mathrm{Ma}]}\end{array}\end{array}$} & I & II & III & IV & V & VI & VII & VIII & IX & X & XI & XII & XIII & XIV & XV & XVI & XVII & $\begin{array}{c}\text { Total } \\
\text { time of } \\
\text { flight } \\
{[\mathrm{min}]}\end{array}$ \\
\hline 0.7 & 109 & 110 & 110 & 111 & 111 & 109 & 107 & 107 & 106 & 106 & 106 & 106 & 104 & 104 & 104 & 104 & 104 & 30.26 \\
\hline 0.8 & 96 & 96 & 96 & 97 & 97 & 96 & 94 & 94 & 94 & 93 & 93 & 93 & 92 & 92 & 92 & 92 & 92 & 26.70 \\
\hline 0.85 & 91 & 91 & 91 & 92 & 92 & 90 & 89 & 89 & 89 & 88 & 88 & 88 & 87 & 87 & 87 & 87 & 87 & 25.22 \\
\hline
\end{tabular}

The determined total time of flight in the cruise phase enables to determine the total emission of individual pollutants for the analysed variants of the cruise phase (different cruising altitudes and flight speeds).

\section{Analysis of the results}

Based on the determined total time of flight in the cruise phase, taking into account the influence of wind as well as engines operation parameters and their emission indexes resulting 
from flight parameters [6], the total emission of $\mathrm{CO}, \mathrm{HC}, \mathrm{NO}_{\mathrm{x}}$ and $\mathrm{CO}_{2}$ was determined. The results obtained for different variants analysed are presented in Tab. 8.

Tab. 8. Cruising time and corresponding total amount of $\mathrm{CO}, \mathrm{HC}, \mathrm{NO}_{x}$ and $\mathrm{CO}_{2}$ emitted in the cruise phase during the flight from Copenhagen airport to Gdansk airport

\begin{tabular}{|c|c|c|c|c|c|c|c|}
\hline Trajectory & Fight altitude & Flight speed & Total cruising & \multicolumn{4}{|c|}{ Total emission in cruise phase } \\
\cline { 5 - 8 } & {$[\mathrm{m}]$} & {$[\mathrm{Ma}]$} & time $[\mathrm{min}]$ & $E_{\mathrm{CO}}[\mathrm{kg}]$ & $E_{\mathrm{HC}}[\mathrm{kg}]$ & $E_{\mathrm{NO}_{x}}[\mathrm{~kg}]$ & $E_{\mathrm{CO}_{2}}[\mathrm{~kg}]$ \\
\hline 1 & 7000 & 0.7 & 30.42 & 90.87 & 4.54 & 388.89 & 29421.56 \\
\hline 2 & 7000 & 0.8 & 26.69 & 100.49 & 5.02 & 434.78 & 32773.26 \\
\hline 3 & 7000 & 0.85 & 25.15 & 106.37 & 5.32 & 463.15 & 34863.32 \\
\hline 4 & 9000 & 0.7 & 30.26 & 55.55 & 1.39 & 401.73 & 28082.09 \\
\hline 5 & 9000 & 0.8 & 26.66 & 58.30 & 1.46 & 426.21 & 29643.62 \\
\hline 6 & 9000 & 0.85 & 25.16 & 54.08 & 1.56 & 520.59 & 31881.97 \\
\hline 7 & 10000 & 0.7 & 30.26 & 45.51 & 1.52 & 451.77 & 28898.34 \\
\hline 8 & 10000 & 0.8 & 26.70 & 46.16 & 1.54 & 463.33 & 29527.01 \\
\hline 9 & 10000 & 0.85 & 25.22 & 47.20 & 1.57 & 502.90 & 30226.65 \\
\hline
\end{tabular}

The results of the research conducted, summarized in Tab. 8, enable the following remarks:

1. The total cruising time for particular cruising altitudes is similar - it is about 25 to 30 min, i.e. the difference is about 5 minutes (about 12\%) at a given cruising altitude, which results from a different value of the flight speed (from 0.7 to $0.85 \mathrm{Ma}$ ).

2. The emission of particular pollutants increases as the flight speed increases, e.g. for $H=7 \mathrm{~km}$, the increase of speed from $0.7 \mathrm{Ma}$ to $0.85 \mathrm{Ma}$ results in the increase in emissions of: $\mathrm{CO}$ from $90.87 \mathrm{~kg}$ to $106.37 \mathrm{~kg}$, HC from $4.54 \mathrm{~kg}$ to $5.32 \mathrm{~kg}, \mathrm{NO}_{\mathrm{x}}$ from $388.89 \mathrm{~kg}$ to $463.15 \mathrm{~kg}$ and $\mathrm{CO}_{2}$ from $29421.56 \mathrm{~kg}$ to $34863.32 \mathrm{~kg}$ (i.e. about $17-18 \%$ ).

3. The emissions of $\mathrm{CO}, \mathrm{HC}$ and $\mathrm{CO}_{2}$ at the same Mach speed decrease with increasing cruising altitude, e.g. at $0.85 \mathrm{Ma}, \mathrm{CO}$ emission at $H=7 \mathrm{~km}$ is $106.37 \mathrm{~kg}$, while at $H=9 \mathrm{~km}$ is almost half less $-54.08 \mathrm{~kg}$, and at $H=10 \mathrm{~km}$ is $47.20 \mathrm{~kg}$, which is more than twice less than at $H=7 \mathrm{~km}$. In case of $\mathrm{NO}_{\mathrm{x}}$, along with the increase of the cruising altitude at the same Mach speed, the emission of this pollutant increases. The phenomena described are related to the increase of the engine load. With the increase of the cruising altitude for the same flight speed, the engine will operate at a higher load and rotational speed. Therefore, the combustion parameters in the combustion chamber will undergo under more favourable conditions (at a higher temperature). Consequently, this will result in a decrease of emission indexes for $\mathrm{HC}$ and $\mathrm{CO}$, an increase of emission index for $\mathrm{NO}_{\mathrm{x}}$. At the same time, along with a higher cruising altitude, fuel consumption will decrease [6]. Because of these two factors (change in emission indexes and decrease in fuel consumption along with increasing cruising altitude), the total emission of $\mathrm{CO}$ and $\mathrm{HC}$ will decrease and emission of $\mathrm{NO}_{\mathrm{x}}$ will increase. Lower fuel consumption will result in a decrease in $\mathrm{CO}_{2}$ emissions as well.

\section{Conclusions}

The results of the research conducted allow for determining the usefulness of the developed emission model and the possibility of its application for further research and analysis. Taking into account the configuration of the aircraft (aerodynamic parameters), the flight speed and altitude) and meteorological conditions, it is possible to plan the trajectory of an aircraft in cruise phase in terms of the minimization of emissions of pollutants in its engines exhausts.

The results of the exemplary analysis for an exemplary passenger aircraft in terms of this criterion show that it is possible to indicate such a trajectory that is characterized by the lowest total emission of a given pollutant. 
The selection of the most advantageous flight trajectory in terms of minimizing the emission of all pollutants being analysed constitutes a difficult and complex issue. To conduct such an analysis it is necessary to determine accurately the meteorological parameters during the flight and the engines parameters. This is an issue that can be solved using optimization methods, which constitutes the author's research.

\section{References}

[1] Cichosz, E., Kordziński, W., Łyżwiński, M., Szczeciński, S., Charakterystyka i zastosowanie napędów - napędy lotnicze, Wydawnictwa Komunikacji i Łączności, Warszawa 1980.

[2] Flightradar24.com.

[3] Jackson, P., Jane's All the World's Aircraft, 2013-2014, Development \& Production, FRAeS, Publ. Jane's Information Group, London, UK 2014.

[4] Pawlak, M., Kuźniar, M., Analysis of the Wind Dependent Duration of the Cruise Phase on Jet Engine Exhaust Emissions, Journal of KONES Powertrain and Transport, Vol. 25, No. 3, pp. 371-376, Warsaw 2018.

[5] Pawlak, M., Majka, A., Kuźniar, M., Pawluczy, J., Analysis of Wind Impact on Emission of Selected Exhaust Compounds in Jet Engines of a Business Jet Aircraft in Cruise Phase, Combustion Engines, Vol. 173, No. 2, pp. 55-60, 2018.

[6] Pawlak, M., Metoda modelowania emisji szkodliwych i toksycznych sktadników spalin turbinowych silników odrzutowych samolotów pasażerskich $w$ warunkach przelotowych, Wyd. Uniwersytetu Morskiego w Gdyni, Gdynia 2019.

[7] Schaefer, M., Bartosch, S., Overview on Fuel Flow Correlation Methods for the Calculation of $\mathrm{NO}_{x}, \mathrm{CO}$ and HC Emissions and Their Implementation into Aircraft Performance Software, Interner Bericht, Deutsches Zentrum für Luft- und Raumfahrt (DLR), Institut für Antriebstechnik, Köln, Germany 2013.

[8] Wilson, D. G., Korakianitis, T., The Design of High-Efficiency Turbomachinery and Gas Turbines, The MIT Press, 2nd ed., Cambridge, MA, USA 2014.

[9] Windy.com.

Manuscript received 08 July 2019; approved for printing 26 September 2019 